\title{
Analisis Perbandingan Kehilangan Gaya Prategang pada Jembatan Fly Over Metode Stressing Satu Arah dan Dua Arah
}

\author{
Permita Ulandari, Suhendra*, Ria Zulfiati \\ Program Studi Teknik Sipil Universitas Batanghari Jambi \\ *Correspondence email: suhendra_domas@yahoo.com
}

\begin{abstract}
Abstrak. Stressing adalah proses penarikan kabel tendon yang ada di dalam girder untuk menjadikan girder sebagai beton pretegang. Stressing satu arah yaitu sistem stressing kabel strand dengan hanya menarik salah satu ujung kabel strand saja. Sedangkan stressing dua arah yaitu dengan menarik kedua ujung kabel. Kehilangan gaya prategang yakni berkurangnya gayagaya prategang yang bekerja pada suatu baja / kabel prategang (tendon) di setiap tahap-tahapan pembebanan. Sehingga harus diperhitungkan berapa total kehilangan prategang yang terjadi diakibatkan oleh stressing satu arah dan dua arah. Tujuan penelitian ini antara lain untuk mengetahui bagaimana pengaruh metode stressing pada saat pelaksanaan pekerjaan jembatan fly over terhadap kehilangan gaya prategang dan mengetahui bagaimana kehilangan gaya prategang akibat pengaruh metode stressing pada jenis girder yaitu PC I girder. Metode stressing pada proyek pembangunan fly over Bukittinggi berpengaruh pada kehilangan gaya prategang khususnya pada kehilangan prategang karena gesekan tendon dan relaksasi pada baja. Berdasarkan data yang diperoleh, di dapatkan hasil analisa kehilangan gaya prategang diakibatkan oleh stressing satu arah yaitu 29,696\% dan metode stressing dua arah yaitu $28,764 \%$. Namun telah dilakukan tegangan awal yang lebih besar pada saat stressing untuk mengatasi kehilangan prategang karena gesekan pada tendon dan slip angkur. Maka nilai kehilangan gaya prategang yang diakibatkan oleh metode stressing satu arah yaitu 17,778\% dan metode stressing dua arah yaitu 17,994\%. Kontrol keamanan struktur telah memenuhi syarat keamanan struktur dengan tegangan dan lendutan yang terjadi kurang dari tegangan dan lendutan yang diizinkan.
\end{abstract}

Kata Kunci: Kehilangan Prategang, Metode Stressing, Jembatan Fly Over.

\section{PENDAHULUAN}

Beton yaitu sebuah bahan kuat tekan tinggi, akan tetapi kuat tarik yang rendah. Sementara baja yakni material yang memiliki kuat tarik yang sangat tinggi. Sehingga dengan menggabungkan beton dan baja sebagai bahan struktur maka tegangan tekan dipikul oleh beton sementara tegangan tarik dipikul oleh baja. Saat ini mulai dikenal jembatan yang menggunakan beton prategang pada strukturnya. Penggunaan system beton prategang untuk struktur jembatan biasanya diterapkan pada jembatan bentang menengah, bentang panjang dan jembatan layang (fly over). Jembatan layang yaitu sebuah model jembatan yang melintas di atas jalan. Jalan layang yaitu jalan yang dibangun tidak sebidang melayang yang bertujuan untuk menghindari daerah/kawasan yang selalu menghadapi permasalahan kemacetan lalu lintas, melewati persilangan kereta api untuk meningkatkan keselamatan lalu lintas dan efisiensi. Jalan layang adalah perlengkapan jalan bebas hambatan untuk mengatasi hambatan karena konflik di persimpangan, melalui kawasan kumuh yang sukar ataupun melalui kawasan daerah rawa-rawa. (Ramadhan, 2015)

Proses pemberian tegangan bisa dilakukan sebelum beton dicetak (pratarik) atau sesudah beton dicetak (pascatarik). Pemberian tegangan pada beton prategang pasca tarik bisa dilakukan melalui dua metode antara lain stressing satu arah dan dua arah. Stressing yaitu proses penarikan kabel tendon yang ada di dalam girder yang bertujuan untuk menjadikan girder sebagai beton pretegang. Stressing satu arah yaitu sistem stressing kabel strand dengan hanya menarik salah satu ujung kabel strand saja. Sedangkan stressing dua arah yaitu sistem penarikan kabel strand dengan menarik kedua ujung kabel. Pemberian tegangan dengan menggunakan kedua metode stressing mengakibatkan kehilangan gaya prategang yang berbeda pada beton. Kehilangan gaya prategang yaitu berkurangnya gaya prategang yang bekerja pada baja / kabel prategang (tendon) pada tahap-tahap pembebanan. Sehingga harus diperhitungkan berapa total kehilangan prategang yang terjadi diakibatkan oleh stressing satu arah dan dua arah.

Adapun tujuan penelitian ini antara lain untuk mengetahui bagaimana pengaruh metode stressing pada saat pelaksanaan pekerjaan jembatan fly over terhadap kehilangan gaya prategang dan mengetahui bagaimana kehilangan gaya prategang akibat pengaruh metode stressing pada jenis girder yaitu PC I girder.

\section{Jembatan}

Jembatan yaitu suatu konstruksi sarana transportasi jalan untuk menghubungkan satu tempat ke tempat lainnya yang terputus akibat suatu rintangan tanpa harus menutup atau menimbun rintangan tersebut seperti lembah, sungai, drainase, jalan kereta api, jurang, jalan kendaraan, dan sebagainya. Konstruksi jembatan fly over antara lain terdiri dari struktur bangunan bawah, struktur bangunan atas dan bangunan pelengkap. Struktur bangunan bawah antara lain pondasi, pilar dan abutment. Sedangkan struktur bangunan atas antara lain pelat lantai, tiang sandaran, girder, trotoar, kerb, beton, aspal. Serta bangunan pelengkap antara lain wing wall, pelat injak, lampu jalan dan lainnya. 


\section{Beton Prategang}

Beton yaitu suatu material yang memiliki kuat tekan tinggi tetapi kuat tarik yang rendah. Sementara baja yaitu material yang memiliki kuat tarik yang sangat tinggi sehingga dengan kombinasi kedua material tersebut maka akan tercipta material yang dapat menahan tekan dan tarik yang biasa dikenal sebagai beton bertulang. Pada system beton bertulang, beton hanya memikul tegangan tekan sedangkan baja memikul tegangan tarik. Sehingga pada beton bertulang, penampang beton tidak efektif $100 \%$ difungsikan. Hal ini dikarenakan bagian tertarik beton tidak diperhitungkan sebagai pemikul tegangan. Untuk mengatasi beberapa permasalahan tersebut, beton diberi tegangan awal sebelum beban-beban bekerja sehingga seluruh penampang beton dalam keadaan tertekan seluruhnya. Inilah yang disebut dengan beton prategang (Prestressed Concrete).

\section{Perhitungan Struktur Beton Prategang.}

\section{Gaya prategang}

Tegangan yang diakibatkan oleh gaya prategang yaitu $=-\frac{\mathrm{P}}{\mathrm{A}} \pm \frac{\mathrm{P}}{\mathrm{W}}$

Tegangan yang diakibatkan oleh beban sendiri maupun beban dari luar $= \pm \frac{\mathrm{M}}{\mathrm{W}}$

Dengan demikian besar tegangan maksimum pada serat penampang (Andri Budiadi, 2008) dapat dihitung dengan rumus :

$\sigma=-\frac{P}{A} \pm \frac{P}{W} \pm \frac{M}{W}$

dimana :

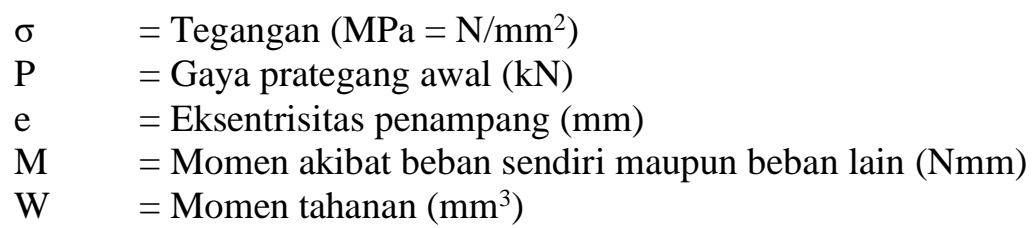

\section{Tegangan Izin pada Beton Prategang (SNI 2847:2013)}

Tegangan beton sesaat sesudah penyaluran gaya prategang (sebelum terjadinya kehilangan prategang sebagai fungsi waktu) tidak boleh melampaui nilai berikut :

a. Tegangan izin serat tekan $=0,6 \mathrm{x}$ fi'

b. Tegangan izin serat tarik $=0,8 \times \sqrt{\mathrm{fci}^{\prime}}$

Tegangan izin pada keadaan servis terjadi pada tahap beban kerja setelah memperhitungkan kehilangan prategang tidak boleh melampaui nilai berikut :

a. Tegangan izin serat tekan $=0,45 \mathrm{x}$ fc'

b. Tegangan izin serat tarik $=1,59 \times \sqrt{\mathrm{fc}^{4}}$

\section{Kontrol Lendutan}

Lendutan ke bawah akibat beban merata bisa ditentukan dengan persamaan berikut :

$\delta=\frac{5 \times \mathrm{qx} \mathrm{L}^{4}}{384 \times \mathrm{Ecx} \mathrm{I}}$

dimana:

$\delta=$ Lendutan yang terjadi $(\mathrm{mm})$

$\mathrm{q}=$ Beban merata $(\mathrm{t} / \mathrm{m})$

$\mathrm{L} \quad=$ Panjang balok girder $(\mathrm{m})$

Ec $\quad=$ Modulus elastisitas beton $\left(\mathrm{kg} / \mathrm{cm}^{2}\right)$

$\mathrm{I}=$ Momen inersia penampang girder $\left(\mathrm{cm}^{4}\right)$

Kehilangan Gaya Prategang Akibat Stressing Satu Arah dan Dua Arah Pada Sistem Prategang Post Tensioning

Untuk sistem post tensioning, apabila tendon lebih dari satu dan tendon-tendon tersebut dilakukan penarikan secara berurutan, maka gaya-gaya prategang terjadi secara bertahap yang bekerja di beton, beton akan bertambah 
Permita Ulandari, Suhendra dan Ria Zulfiati, Analisis Perbandingan Kehilangan Gaya Prategang pada JembatanFly Over Metode Stressing Satu Arah dan Dua Arah

pendek jika setiap kabel diikatkan padanya dan kehilangan gaya prategang berbeda-beda di setiap tendon. Besarnya perpendekan elastis beton dapat dihitung menggunakan persamaan (T.Y Lin, 1996):

$$
\mathbf{f}^{\prime} \mathbf{p}_{\mathrm{ES}}=\frac{\mathbf{n x P t}}{\mathbf{A}} \text { adapun } \mathbf{n}=\frac{\mathbf{E}_{\mathbf{p}}}{\mathbf{E}_{\mathbf{c}}}
$$

dimana,

$$
\begin{array}{ll}
\mathrm{n} & =\text { Rasio modular } \\
\mathrm{Ep} & =\text { Modulus elastisitas baja prategang } \\
\mathrm{Ec} & =\text { Modulus elastisitas beton } \\
\mathrm{Pt} & =\text { Gaya prategang awal } \\
\mathrm{A} & =\text { Luas penampang beton }
\end{array}
$$

\section{Kehilangan Prategang karena Gesekan Tendon}

Untuk menentukan kehilangan prategang akibat gesekan tendon (Edward G. Nawy, 2001) dapat dihitung dengan rumus berikut :

$$
\mathbf{f}^{\prime} \mathbf{p}_{\mathrm{F}}=\mathbf{f p} \times(\mu \mathrm{a}+\mathbf{K L})
$$

dimana :

$\mathrm{f}^{\prime} \mathrm{p}_{\mathrm{F}} \quad=$ kehilangan prategang total karena gesekan pada tendon

$\mathrm{fp} \quad=$ Tegangan tarik (MPa)

$\alpha \quad=$ Sudut kelengkungan pada tendon (rad)

$\mathrm{K}=$ Koefisien gesek panjang (wobble)

$\mathrm{L} \quad=$ Panjang bentang $(\mathrm{m})$

Untuk menghitung kehilangan gaya prategang total akibat stressing kedua-dua ujungnya karena pengaruh lengkungan maupun panjang kabel dapat ditentukan dengan persamaan (T.Y Lin, 1996) sebagai berikut :

$$
\frac{\mathrm{F}_{2}-\mathrm{F}_{1}}{\mathrm{~F}_{1}}=-\mathrm{KL}-\boldsymbol{\mu \mathrm { a }}
$$

dimana :

$\mathrm{F}_{1} \quad=$ Besarnya gaya prategang di titik 1

$\mathrm{F}_{2} \quad=$ Besarnya gaya prategang di titik 2

$\mathrm{K}=$ Koefisien gesek panjang (wobble)

$\mathrm{L} \quad=$ Panjang bentang $(\mathrm{m})$

$\mu \quad=$ Koefisien kelengkungan

$\alpha \quad=$ Sudut kelengkungan pada tendon $(\mathrm{rad})$

Menurut SNI 02-2847-2002 kehilangan tegangan yang diakibatkan oleh friksi (gesekan) pada sebuah tendon dapat dihitung menggunakan persamaan :

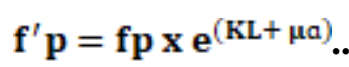

dimana :

$\mathrm{f}^{\prime} \mathrm{p}_{\mathrm{F}} \quad=$ kehilangan gaya prategang total karena gesekan pada tendon

$\mathrm{fp} \quad=$ Tegangan tarik $(\mathrm{MPa})$

$\mathrm{e}^{2}=2,7183$

$\mathrm{K} \quad=$ Koefisien gesek panjang (wobble)

$\mathrm{L} \quad=$ Panjang bentang $(\mathrm{m})$

$\mu \quad=$ Koefisien kelengkungan

$\alpha \quad=$ Sudut kelengkungan pada tendon $(\mathrm{rad})$

\section{Kehilangan Prategang karena Slip Angkur}

Untuk menentukan kehilangan gaya prategang yang diakibatkan oleh slip angkur (Andri Budiadi, 2008) dapat ditentukan menggunakan persamaan berikut : 
$\mathbf{f}^{\prime} \mathbf{p}_{\mathbf{A}}=\Delta \mathbf{L}=\frac{\mathbf{f}_{\mathrm{p}}}{\mathbf{E}_{\mathbf{p}}} \mathbf{L}$

dimana :

$\mathrm{f}^{\prime} \mathrm{p}_{\mathrm{A}} \quad=$ kehilangan prategang total karena slip angkur

$\mathrm{fp} \quad=$ Tegangan tarik (MPa)

Ep $\quad=$ Modulus elastisitas tendon (MPa)

$\mathrm{L} \quad=$ Panjang tendon $(\mathrm{mm})$

Pada saat stressing dua arah kehilangan gaya prategang terjadi diakibatkan adanya blck-blok pada angkur pada saat gaya pendongkrak ditransfer ke angker. Cara mudah untuk mengatasi kehilangan prategang ini adalah dengan memberikan kelebihan tegangan. Pada umumnya besarnya kehilangan karena dudukan angkur bervariasi antara $1 / 4$ in dan $3 / 8$ in $(9,53 \mathrm{~mm})$ dan dapat dihitung sebagai berikut :

$\mathbf{f}^{\prime} \mathbf{p}_{\mathbf{A}}=\frac{\Delta_{\mathrm{A}}}{\mathrm{L}} \mathbf{E}_{\mathrm{p}}$

dimana :

$\mathrm{f}^{\prime} \mathrm{p}_{\mathrm{A}} \quad=$ kehilangan prategang total karena slip angkur

$\Delta_{\mathrm{A}} \quad=$ Besarnya nilai gelincir angkur

$\mathrm{L} \quad=$ Panjang tendon $(\mathrm{mm})$

Ep $\quad=$ Modulus elastisitas tendon $(\mathrm{MPa})$

\section{Kehilangan Prategang karena Rangkak pada Beton}

Besarnya kehilangan prategang akibat rangkak pada beton (Edward G. Nawy, 2001) dapat dihitung menggunakan rumus :

$\mathbf{f}^{\prime} \mathbf{p}_{\mathrm{CR}}=\mathbf{n} \mathbf{K}_{\mathrm{CR}}\left(\mathbf{f}_{\mathrm{CS}}-\mathbf{f}_{\mathrm{CSD}}\right)$.

$\mathrm{f}_{\mathrm{CS}}=\mathrm{K}_{\mathrm{CR}} \times \mathrm{f}_{\mathrm{CP}}-\mathrm{f}_{\mathrm{g}} \quad \mathrm{f}_{\mathrm{CSD}}=\frac{\text { MMA }_{\mathrm{Me}}}{\mathrm{Ix}}$

dimana :

$\mathrm{f}^{\prime} \mathrm{p}_{\mathrm{CR}}=$ kehilangan prategang total karena rangkak pada beton

$\mathrm{n} \quad=$ rasio modular

$\mathrm{K}_{\mathrm{CR}} \quad=$ Koefisien rangkak, 2 (pratarik) dan 1,6 (pascatarik)

$\mathrm{fc}_{\mathrm{S}} \quad=$ Tegangan di beton pada level pusat berat baja segera setelah transfer

$\mathrm{fc}_{\mathrm{SD}} \quad=$ Tegangan di beton pada level pusat berat baja akibat semua beban mati tambahan yang bekerja setelah prategang diberikan.

$\mathrm{f}_{\mathrm{CP}} \quad=$ Tegangan di beton pada pusat tendon

$\mathrm{M}_{\mathrm{MA}} \quad=$ Momen yang ditimbulkan dari beban mati

\section{Kehilangan Prategang karena Susut pada Beton}

Kehilangan prategang akibat susut pada beton (T.Y Lin, 1996) dapat dihitung dengan rumus :

$\varepsilon s h=8,2 \times 10^{-6}\left(1-0,06 \frac{v}{s}\right) x(100-R H)$

$\mathbf{f}^{\prime} \mathbf{p}_{\text {sh }}=\operatorname{Ksh} \mathrm{x} \operatorname{ssh} \times$ Ep..

dimana :

$\mathrm{f}^{\prime} \mathrm{p}_{\mathrm{CR}} \quad=$ kehilangan prategang total karena susut pada beton

$\varepsilon \quad=$ Regangan susut dalam beton

$\mathrm{V} \quad=$ Volume beton

$\mathrm{S} \quad=$ Luas permukaan beton

$\mathrm{RH}=$ Kelembaban relatif udara

$\mathrm{K}=$ Koefisien susut yang tergantung waktu 
Permita Ulandari, Suhendra dan Ria Zulfiati, Analisis Perbandingan Kehilangan Gaya Prategang pada JembatanFly Over Metode Stressing Satu Arah dan Dua Arah

Ep = Modulus elastisitas tendon

\section{Kehilangan Prategang karena Relaksasi Baja}

Kehilangan prategang yang diakibatkan oleh relaksasi pada baja (Andri Budiadi, 2008) dapat ditentukan dengan persamaan :

$$
\mathbf{f}^{\prime} \mathbf{p}_{\mathrm{RE}}=\left[\mathrm{K}_{\mathrm{RE}}-\mathbf{J}\left(\mathbf{f}^{\prime} \mathbf{p}_{\mathrm{SH}}+\mathbf{f}^{\prime} \mathbf{p}_{\mathrm{CR}}+\mathbf{f}^{\prime} \mathbf{p}_{\mathrm{ES}}\right)\right] \mathbf{C} .
$$

dimana :

$\mathrm{f}^{\prime} \mathrm{p}_{\mathrm{RE}} \quad=$ kehilangan prategang total karena relaksasi pada baja

$\mathrm{K}_{\mathrm{RE}} \quad=$ Koefisien relaksasi

$\mathrm{J} \quad=$ Faktor waktu

$\mathrm{f}^{\prime} \mathrm{p}_{\mathrm{SH}} \quad=$ kehilangan tegangan karena susut pada beton

$\mathrm{f}^{\prime} \mathrm{p}_{\mathrm{CR}} \quad=$ kehilangan tegangan karena rangkak pada beton

$\mathrm{f}^{\prime} \mathrm{p}_{\mathrm{ES}} \quad=$ kehilangan prategang total karena perpendekan elastisitas beton

$\mathrm{C} \quad=$ Faktor relaksasi

\section{METODE}

\section{Jenis Data}

Data primer

Data primer yaitu data yang diperoleh langsung dari subyek penelitian dengan menggunakan alat pengukuran atau alat pengambilan data langsung pada subjek sebagai sumber informasi yang dicari. Data primer tersebut berupa foto dokumentasi

\section{Data Sekunder}

Data sekunder yaitu data yang diperoleh lewat pihak lain, tidak langsung diperoleh oleh peneliti dari subjek penelitiannya. Dalam penelitian ini data yang diperlukan adalah data yang berhubungan dengan permasalahan penelitian. Data sekunder tersebut berupa shop drawing.

\section{Tempat Penelitian}

Nama Proyek : Pembangunan Fly Over Bukittinggi.

Lokasi Proyek : Jalan By Pass Pasar Aur Kuning Bukit Tinggi, Sumatera Barat

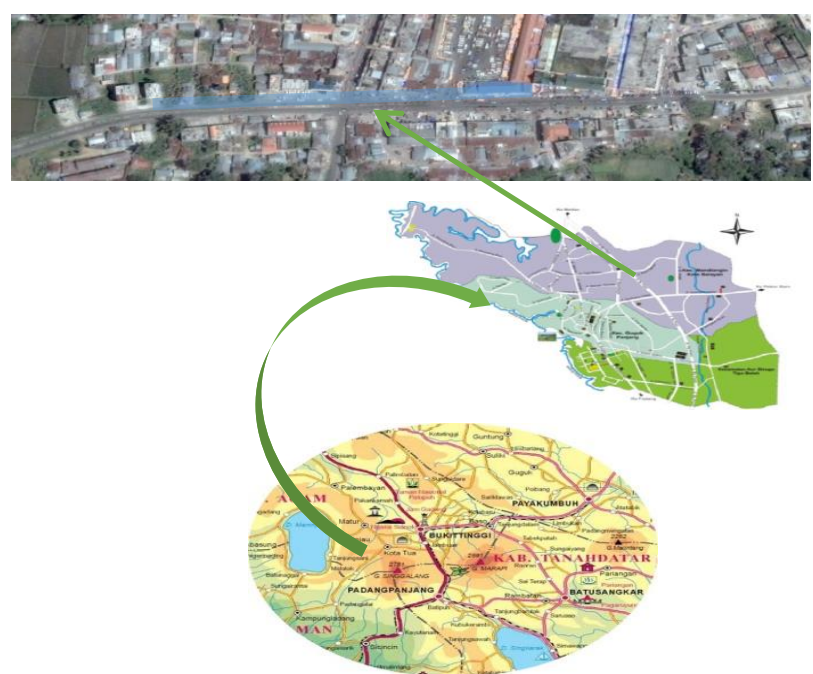

Sumber : Google Earth, 2020

Gambar 1 Lokasi Proyek

Adapun jenis-jenis data dalam penelitian ini adalah :

1. Data Struktur Desain Jembatan
a. Bentang jembatan
b. Lebar jembatan
$=25,6 \mathrm{~m}$
c. Jumlah jalur
$=10 \mathrm{~m}$
$=2$ jalur 

d. Lebar jalur
$=4 \mathrm{~m}$
e. Lebar trotoar dan pagar tepi
$=2 \mathrm{~m}$
f. Tebal plat lantai jembatan
$=0,22 \mathrm{~m}$
g. Tebal aspal
$=0,05 \mathrm{~m}$
h. Tinggi genangan air hujan
$=0,03 \mathrm{~m}$

2. Dimensi Girder
a. Jenis girder
b. Jarak balok
$=\mathrm{PC}$ I girder
$=180 \mathrm{~cm}$
c. Kuat tekan beton $=500 \mathrm{~kg} / \mathrm{cm}^{2}$

\section{Model Jembatan}

Dalam penelitian ini jembatan yang digunakan yaitu jembatan beton prategang pasca tarik dengan girder PC I girder. Dengan panjang bentang 25,6 meter dan lebar jembatan 10 meter.

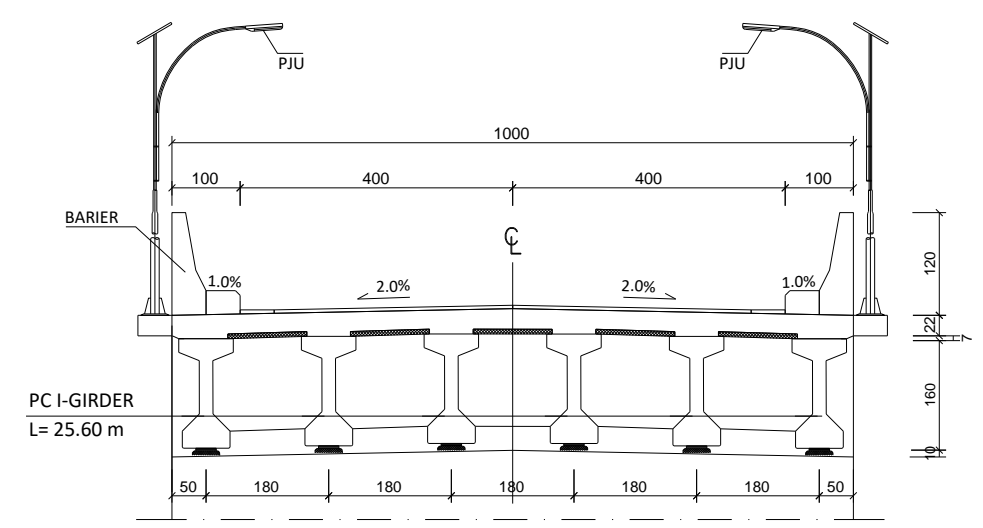

Sumber : Shop Drawing, 2014

Gambar 2 Potongan Melintang Jembatan

\section{Prosedur Penelitian}

Adapun langkah-langkah dalam penelitian yang akan dilakukan antara lain :

1. Menentukan data struktur jembatan dan profil girder

2. Mengolah data yang telah ditentukan yang akan digunakan pada perhitungan, seperti :

a. Menghitung analisis penampang girder

b. Menghitung pembebanan jembatan

3. Melakukan analisis struktur girder beton prategang pada masing-masing girder antara lain :
a. Menentukan gaya prategang
b. Menentukan jumlah lintasan tendon
c. Menghitung kehilangan gaya prategang yang diakibatkan oleh metode stressing yaitu satu arah dan dua arah
d. Menghitung control lendutan dan tegangan

4. Menyimpulkan bagaimana perbedaan kehilangan gaya prategang yang diakibatkan oleh metode stressing yaitu satu arah dan dua arah

\section{HASIL DAN PEMBAHASAN \\ Data Analisis Penampang} ini.

Untuk melakukan analisis PC I Girder dilakukan pembagian penampang seperti terlihat pada Gambar dibawah 
Permita Ulandari, Suhendra dan Ria Zulfiati, Analisis Perbandingan Kehilangan Gaya Prategang pada JembatanFly Over Metode Stressing Satu Arah dan Dua Arah

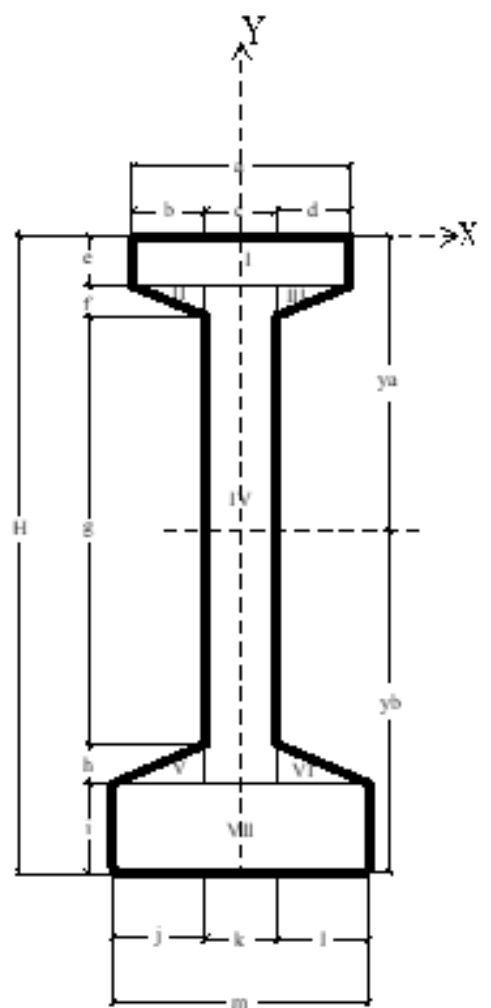

Ket:

$\mathrm{a}=0,550 \mathrm{~m}$

$\mathrm{b}=0,185 \mathrm{~m}$

$\mathrm{c}=0,180 \mathrm{~m}$

$\mathrm{d}=0,185 \mathrm{~m}$

$\mathrm{e}=0,125 \mathrm{~m}$

$\mathrm{f}=0,075 \mathrm{~m}$

$\mathrm{g}=1,075 \mathrm{~m}$

$\mathrm{h}=0,100 \mathrm{~m}$

$\mathrm{i}=0,225 \mathrm{~m}$

$\mathrm{j}=0,235 \mathrm{~m}$

$\mathrm{k}=0,180 \mathrm{~m}$

$1=0,235 \mathrm{~m}$

$\mathrm{m}=0,650 \mathrm{~m}$

Sumber : Data Olahan, 2020

Gambar 3 Pembagian Penampang PC I Girder

Tabel 1. Perhitungan Luas dan Titik Berat PC I Girder

\begin{tabular}{|c|c|c|c|}
\hline \multirow[t]{2}{*}{ Bagian } & Luas (Ai) & $\begin{array}{l}\text { Jarak Titik Berat } \\
\text { Bagian ke Acuan }\end{array}$ & $\begin{array}{c}\text { Luas x Jarak Titik } \\
\text { Berat }\end{array}$ \\
\hline & $\left(\mathrm{m}^{2}\right)$ & $(\mathrm{m})$ & $\left(\mathrm{m}^{3}\right)$ \\
\hline $\mathrm{I}$ & $\mathrm{A}_{\mathrm{I}}=\mathrm{a} \times \mathrm{e}=0,55 \times 0,125=0,0688$ & 0,0625 & 0,0043 \\
\hline II & $A_{I I}=1 / 2 \times b \times f=1 / 2 \times 0,185 \times 0,075=0,0069$ & 0,15 & 0,0010 \\
\hline III & $A_{\text {III }}=1 / 2 \times d \times f=1 / 2 \times 0,185 \times 0,075=0,0069$ & 0,15 & 0,0010 \\
\hline IV & $\mathrm{A}_{\mathrm{IV}}=(\mathrm{f}+\mathrm{g}+\mathrm{h}) \times \mathrm{c}=(0,075+1,075+0,1) \times 0,18=0,2241$ & 0,7375 & 0,1653 \\
\hline $\mathrm{V}$ & $A_{V}=1 / 2 \times h \times j=1 / 2 \times 0,1 \times 0,235=0,0118$ & 1,3083 & 0,0154 \\
\hline VI & $A_{V I}=1 / 2 \times h \times m=1 / 2 \times 0,1 \times 0,235=0,0118$ & 1,3083 & 0,0154 \\
\hline VII & $\mathrm{A}_{\mathrm{VII}}=\mathrm{i} \times \mathrm{n}=0,225 \times 0,65=0,1463$ & 1,4875 & 0,2084 \\
\hline Total & 0,4765 & & 0,4199 \\
\hline
\end{tabular}

Sumber : Data Olahan, 2020

$\mathrm{Ya} \quad=\frac{\mathrm{Y}}{\mathrm{A}}=\frac{0,4199 \mathrm{~m}^{3}}{0,4765 \mathrm{~m}^{2}}=0,8814 \mathrm{~m}$

$\mathrm{Yb}=\mathrm{H}-\mathrm{Ya}=1,6000-0,8814=0,7186 \mathrm{~m}$

Tabel 2. Analisis Penampang

\begin{tabular}{cccccccccc}
\hline Bagian & Luas & $\mathrm{X}$ & $\mathrm{Y}$ & $\mathrm{AX}^{2}$ & $\mathrm{AY}^{2}$ & $\mathrm{Ix}_{0}$ & $\mathrm{Iy}_{0}$ & $\mathrm{Ix}$ & $\mathrm{Iy}$ \\
\hline I & 0,0688 & 0 & 0,0625 & 0 & 0,0003 & 0,0001 & 0,0017 & 0,0004 & 0,0017 \\
II & 0,0069 & 0 & 0,1500 & 0 & 0,0002 & 0,00001 & 0,00004 & 0,0002 & 0,0000 \\
III & 0,0069 & 0 & 0,1500 & 0 & 0,0002 & 0,00001 & 0,00004 & 0,0002 & 0,0000 \\
IV & 0,2241 & 0 & 0,7375 & 0 & 0,1219 & 0,0289 & 0,0006 & 0,1508 & 0,0006 \\
V & 0,0118 & 0 & 1,3083 & 0 & 0,0201 & 0,00002 & 0,0001 & 0,0201 & 0,0001 \\
VI & 0,0118 & 0 & 1,3083 & 0 & 0,0201 & 0,00002 & 0,0001 & 0,0201 & 0,0001 \\
VII & 0,1463 & 0 & 1,4875 & 0 & 0,3236 & 0,0006 & 0,0051 & 0,3242 & + \\
Jumlah & & & & & & & & 0,0051 & 0,5160 \\
\hline
\end{tabular}

Sumber : Data Olahan, 2020 
$\mathrm{Wa}=\frac{\mathrm{Ix}}{\mathrm{Ya}}=\frac{0,5160 \mathrm{~m}^{4}}{0,8814 \mathrm{~m}}=0,59 \mathrm{~m}^{3}$

$\mathrm{Wb} \quad=\frac{\mathrm{Ix}}{\mathrm{Yb}}=\frac{0,5160 \mathrm{~m}^{4}}{0,7186 \mathrm{~m}}=0,718 \mathrm{~m}^{3}$

\section{Pembebanan Jembatan.}

Tabel 3. Resume Momen dan Gaya Geser

\begin{tabular}{clcccc}
\hline No & Jenis Beban & $\begin{array}{c}\text { Kode } \\
\text { Beban }\end{array}$ & Q (T/m) & P (Ton) & Q (Tm) \\
\hline 1 & Berat Sendiri & MS & 2,4130 & & \\
2 & Beban Mati & MA & 0,2509 & & \\
3 & Beban Lajur D & TD & 1,6200 & 12,348 & \\
4 & Gaya Rem & TB & & & 10,7777 \\
5 & Beban Angin & EW & 14,6000 & & \\
6 & Beban Gempa & EQ & 0,3596 & & \\
\hline & Jumlah & MU & 19,2435 & 12,348 & 10,7777 \\
\hline
\end{tabular}

Sumber : Data Olahan, 2020

\section{Gaya Prategang dan Jumlah Tendon}

Berdasarkan Shop Drawing Strand yang digunakan pada PC I girder adalah Strand Ø12.7 mm.

Standard

Tegangan tarik (fp)

$=$ JIS-3536 atau ASTM A-416

Tegangan leleh strand (fy)

$$
\begin{aligned}
& =1.870 \mathrm{Mpa} \\
& =80 \% \times \mathrm{xp}
\end{aligned}
$$$$
=0.80 \times 1870
$$$$
=1.496 \mathrm{MPa}
$$

Jacking Force $=80 \%$ dari UTS

Mutu Beton saat service $=\mathrm{K}-500 \mathrm{Kg} / \mathrm{cm}^{2}=\mathrm{fc}^{\prime}=40 \mathrm{Mpa}$

Mutu Beton saat stressing $\quad=80 \%$ x $40 \mathrm{Mpa}=32 \mathrm{MPa}$

Tegangan tekan beton (fci') $\quad=85 \% \times$ fc' $=0,85 \times 500=425 \mathrm{Kg} / \mathrm{cm}^{2}$

Tegangan izin pada saat initial

Tegangan tekan $\quad=0,60 \times$ fci' $=0,60 \times 425=255 \mathrm{Kg} / \mathrm{cm}^{2}$

Tegangan tarik $\quad=0,80 \times \sqrt{\mathrm{fci}^{\prime \prime}}=0,80 \times \sqrt{425}=16,49 \mathrm{Kg} / \mathrm{cm}^{2}$

Tegangan izin pada saat service
Tegangan tekan
$=0,45 \times \mathrm{fc}^{\prime}=0,60 \times 500=225 \mathrm{Kg} / \mathrm{cm}^{2}$
Tegangan tarik
$=1,59 \times \sqrt{\mathrm{fc}^{4}}=1,59 \times \sqrt{500}=35,55 \mathrm{Kg} / \mathrm{cm}^{2}$

Eksentrisitas tendon

$\mathrm{e}_{\mathrm{s}} \quad=\mathrm{Yb}-\mathrm{z}_{0}=0,7186-0,295=0,4236 \mathrm{~m}=42,3643 \mathrm{~cm}$

Tegangan di serat atas

$\sigma_{\text {top }}=\frac{\text { Pt }}{\mathrm{A}}-\frac{\text { Ptxes }}{\text { Wa }}+\frac{\mathrm{M}_{\text {MS } 1}}{\text { Wa }}$

$\mathrm{Pt}=\frac{16,4924 \times 585.906,7305+9.758 .208}{42,3643-585.906,7305 / 4.764,75}$

$=241.137,911 \mathrm{~kg}=241,1379$ ton

Tegangan di serat bawah

$\sigma_{\text {bot }}=\frac{\text { Pt }}{\mathrm{A}}+\frac{\text { Ptxes }}{\mathrm{Wb}}-\frac{\mathrm{M}_{\text {MS } 1}}{\mathrm{~Wb}}$

$\mathrm{Pt}=\frac{255 \times 718.023,163+9.758 .208}{718.023,163 / 4764,75-42,3643}$

$=1.780 .237,9679 \mathrm{~kg}=1.780,238$ ton

Kesimpulan, diambil nilai Pt yang terkecil $=\quad 241,138$ ton.

Beban putus satu tendon $\left(\mathrm{P}_{\mathrm{b} 1}\right)=156,10 \mathrm{kN}=15,610$ ton. 
Permita Ulandari, Suhendra dan Ria Zulfiati, Analisis Perbandingan Kehilangan Gaya Prategang pada JembatanFly Over Metode Stressing Satu Arah dan Dua Arah

Kehilangan Gaya Prategang.

Tabel 4. Persentase Kehilangan Gaya Prategang

Sumber : Data Olahan, 2020

\begin{tabular}{lcc}
\hline & Satu Arah $(\%)$ & Dua Arah $(\%)$ \\
\hline Perpendekan elastis dan lenturan balok & 1,631 & 1,915 \\
Gesekan Tendon & 10,900 & 10,733 \\
Slip Angkur & 1,018 & 0,037 \\
Rangkak Beton & 4,330 & 4,330 \\
Susut Beton & 1,525 & 1,525 \\
Relaksasi Baja & 10,292 & 10,224 \\
\hline Kehilangan Total & 29,696 & 28,764 \\
\hline
\end{tabular}

Namun telah dilakukan tegangan yang lebih besar untuk mengatasi kehilangan prategang karena gesekan pada tendon dan slip angkur. Maka total kehilangan gaya prategang akibat stressing satu arah dan stressing dua arah dapat dilihat pada tabel 5 .

Tabel 5. Total Persentase Kehilangan Gaya Prategang

\begin{tabular}{lcc}
\hline & Satu Arah $(\%)$ & Dua Arah $(\%)$ \\
\hline Perpendekan elastis dan lenturan balok & 1,631 & 1,915 \\
Rangkak Beton & 4,330 & 4,330 \\
Susut Beton & 1,525 & 1,525 \\
Relaksasi Baja & 10,292 & 10,224 \\
\hline Kehilangan Total & 17,778 & 17,994 \\
\hline
\end{tabular}

Sumber : Data Olahan, 2020

\section{Analisa Tegangan}

1. Tegangan pada saat initial

Tegangan atas :

$\sigma_{\text {top }}=\frac{\mathrm{Pt}}{\mathrm{A}}-\frac{\mathrm{M}_{\mathrm{MS}}}{\mathrm{Wa}}=\frac{241,1379}{0,4765}-\frac{197,6770}{0,59}=158,4452$ ton $/ \mathrm{m}^{2}=15,8445 \mathrm{~kg} / \mathrm{cm}^{2}$

Tegangan bawah :

$\sigma_{\text {bot }}=\frac{\mathrm{Pt}}{\mathrm{A}}+\frac{\mathrm{M}_{\mathrm{MS}}}{\mathrm{Wb}}=\frac{241,1379}{0,4765}+\frac{197,6770}{0,7180}=781,3945 \mathrm{ton} / \mathrm{m}^{2}=78,1395 \mathrm{~kg} / \mathrm{cm}^{2}$

2. Tegangan pada saat service

Tegangan atas :

$\sigma_{\text {top }}=\frac{\mathrm{Pt}}{\mathrm{A}}+\frac{\mathrm{M}_{\mathrm{MA}}}{\mathrm{Wc}}=\frac{241,1379}{0,4765}+\frac{20,56}{0,44}=552,7492$ ton $/ \mathrm{m}^{2}$

Tegangan bawah :

$\sigma_{\text {bot }}=\frac{\mathrm{Pt}}{\mathrm{A}}-\frac{\mathrm{M}_{\mathrm{MA}}}{\mathrm{Wb}}=\frac{241,1379}{0,4765}-\frac{20,56}{0,7180}=347,4595 \mathrm{ton} / \mathrm{m}^{2}=34,7460 \mathrm{~kg} / \mathrm{cm}^{2}$

\section{Kontrol Tegangan}

1. Kontrol Tegangan pada saat initial Tegangan atas $\left(\sigma_{\text {top }}\right)=15,8445 \mathrm{~kg} / \mathrm{cm}^{2} \leq$ Tegangan Ijin $=16,49 \mathrm{~kg} / \mathrm{cm}^{2}(\mathrm{OK})$

Tegangan bawah $\left(\sigma_{\text {bot }}\right)=78,139 \mathrm{~kg} / \mathrm{cm}^{2} \leq$ Tegangan Ijin $=255 \mathrm{~kg} / \mathrm{cm}^{2}(\mathrm{OK})$

2. Kontrol Tegangan pada saat service

Tegangan atas $\left(\sigma_{\text {top }}\right)=55,2749 \mathrm{~kg} / \mathrm{cm}^{2} \leq$ Tegangan Ijin $=225 \mathrm{~kg} / \mathrm{cm}^{2}(\mathrm{OK})$

Tegangan bawah $\left(\sigma_{\text {bot }}\right)=34,75 \mathrm{~kg} / \mathrm{cm}^{2} \leq$ Tegangan Ijin $=35,55 \mathrm{~kg} / \mathrm{cm}^{2}(\mathrm{OK})$

\section{Analisa Lendutan}

$\delta=\frac{5 \times \text { q X L }^{4}}{384 \times \text { Ec XI }}=\frac{5 \times 1,1912 \times 25,6^{4}}{384 \times 3.031 .148,25 \times 0,5160}=0,004259 \mathrm{~m}$

Kontrol lendutan $=\mathrm{L} / 800=25,6 / 800=0,032 \mathrm{~m}$

$=0,004259 \mathrm{~m} \leq 0,032 \mathrm{~m}(\mathrm{OK})$ 
Permita Ulandari, Suhendra dan Ria Zulfiati, Analisis Perbandingan Kehilangan Gaya Prategang pada JembatanFly Over Metode Stressing Satu Arah dan Dua Arah

\section{SIMPULAN}

Adapun kesimpulan yang dapat dirangkum dalam Tugas Akhir ini adalah :

1. Metode stressing pada proyek pembangunan fly over Bukittinggi metode post tensioning berpengaruh pada kehilangan gaya prategang khususnya pada kehilangan prategang karena gesekan tendon dan relaksasi pada baja.

2. Berdasarkan data yang diperoleh dari proyek pembangunan fly over Bukittinggi di dapatkan hasil analisa kehilangan gaya prategang yang diakibatkan oleh metode stressing satu arah yaitu 29,696\% dan metode stressing dua arah yaitu $28,764 \%$.

3. Namun telah dilakukan tegangan awal yang lebih besar pada saat stressing untuk mengatasi kehilangan prategang karena gesekan pada tendon dan slip angkur. Maka nilai kehilangan gaya prategang yang diakibatkan oleh metode stressing satu arah yaitu 17,778\% dan metode stressing dua arah yaitu 17,994\%.

4. Kontrol keamanan struktur telah memenuhi syarat keamanan struktur dengan tegangan dan lendutan yang terjadi kurang dari tegangan dan lendutan yang diizinkan.

\section{DAFTAR PUSTAKA}

Budiadi, Andri. 2008. Desain Praktis Beton Prategang. Yogyakarta: Andi

Darmawan, M. Sigit. 2008. Perhitungan Kehilangan Pratekan Total dengan Memakai Teori Kemungkinan. Jurnal for Strata Degree. Surabaya: Institut Teknologi Sepuluh Nopember.

Nawy, Edward G. 2001. Beton Prategang Suatu Pendekatan Mendasar. Edisi Ketiga Jilid 1. Jakarta: Erlangga

Ned, T.Y Lin dan H. Burns. 1996. Desain Struktur Beton Prategang Edisi Ketiga Jilid 1. Jakarta: Erlangga

Ramadhan. 2015. Devinisi Jalan Fly Over. Tersedia : http://DevinisiJalan FlyOver.html

Rizkia, Selvia Rahma. 2017. Analisis Perbandingan Kehilangan Prategang Akibat Metode Stressing Satu Arah dan

Dua Arah Pada Jembatan Beton Prategang. Jurnal for Strata Degree. Lampung: Universitas Lampung.

SNI 1725:2016. 2016. Pembebanan Untuk Jembatan. Jakarta: Badan Standarisasi Nasional.

SNI 2833:2016. 2016. Perencanaan Jembatan Terhadap Beban Gempa. Jakarta: Badan Standarisasi Nasional.

SNI 2847:2013. 2013. Persyaratan Beton Struktural Untuk Bangunan Gedung. Jakarta: Badan Standarisasi Nasional.

SNI 03-2847-2002. 2002. Tata Cara Perhitungan Struktur Beton Untuk Bangunan Gedung (Beta Version). Jakarta :

Badan Standarisasi Nasional

SNI T-12-2004. 2004. Perencanaan Struktur Beton Untuk Jembatan. Jakarta : Badan Standarisasi Nasional 